\title{
PENGGUNAAN KAYU BAKAR UNTUK RUMAH TANGGA DI DESA SEKITAR TAMAN HUTAN RAYA RAJOLELO BENGKULU
}

\author{
Putranto BAN 1 \\ Joni Syariffudin² \\ ${ }^{1}$ Staf Pengajar urusan Kehutanan Universitas Bengkulu \\ ${ }^{2}$ Alumni Jurusan Kehutanan Universitas Bengkulu
}

\begin{abstract}
The study aims to observe the use of fuelwood by people living near Tahura Rajolelo Bengkulu. This study explored two villages as the subjects, desa Dusun Baru I and desa Tanjung Terdana. Thirty-one $(10 \%$ IS) households were selected (using stratified random sampling methods) as samples. Data of fuelwood consumption was measured by directly weighing the fuelwood used for daily activities. Fuelwood preference, methods of collecting fuelwood and other social-economic data were gathered by interviewing the selected families. From the study it was figured out that; (1) fuelwood consumption of the families in desa Dusun Baru I and Tanjung Terdana were very high, (2) the high consumption is the impact of the consumption for protecting cattle and the inefficient use of fuelwood for cooking, (3) the fuelwood consumption of the family was significantly affected by the number of people in the family, and (4) women held the main role in collecting fuelwood.
\end{abstract}

Keywords: fuelwood, tahura, Rajolelo

\section{PENDAHULUAN}

Sampai saat ini kebutuhan energi rumah tangga di pedesaan masih ditopang oleh kayu bakar dan limbah pertanian. Di kawasan pedesaan, terutama di daerah terpencil masyarakat masih menggunakan lebih dari $60 \%$ kebutuhan energinya dari kayu bakar atau biomassa (Anonimus 1987). Lebih lanjut dijelaskan bahwa 80-85\% pemenuhan kebutuhan energi rumah tangga dipedesaan berasal dari kayu-kayuan dan biomassa yang berada di pekarangan, di tegalan milik sendiri, dari kawasan hutan yang berada didekat pemukiman, atau dari perkebunan, yang diambil tanpa harus membeli. Sementara itu, tingkat konsumsi kayu bakar beragam dari satu rumah tangga kerumah tangga yang lain. Hal ini disebabkan oleh berbagai faktor, antara lain faktor jumlah anggota keluarga, pendapatan, barang substitusi serta akses terhadap kayu bakar (Madjid 1998).

Desa Dusun Baru I dan Desa Tanjung Terdana merupakan desa yang berbatasan langsung dengan Taman Hutan Raya Rajolelo (Tahura Rajolelo) Bengkulu. Sebagian besar penduduk di desa tersebut masih menjadikan kawasan Tahura sebagai sumber kayu bakar 
untuk kebutuhan rumah tangga. Kegiatan ini bisa berdampak terhadap kondisi dan fungsi Tahura. Untuk mengantisipasi dan menanggulangi kemungkinan dampak negatif terhadap keberadaan dan fungsi Tahura, informasi tentang konsumsi kayu bakar untuk rumah tangga serta aspekaspek yang berkait dengan asal, sumber dan preferensi jenis kayu bakar yang digunakan sangat diperlukan.

Penelitian ini dimaksudkan untuk mengetahui banyaknya konsumsi kayu bakar untuk keperluan rumah tangga, mengetahui faktor-faktor yang mempengaruhi konsumsi, jenis-jenis pohon yang digunakan/disukai untuk kayu bakar, serta sistem pemungutan kayu bakar yang dikonsumsi oleh masyarakat Desa Dusun Baru I dan Tanjung Terdana.

\section{METODE PENELITIAN}

Penelitian dilakukan di desa Dusun Baru I Talang Empat dan Desa Tanjung Terdana Pondok Kelapa Bengkulu Utara. Sampel responden diambil secara acak berstratifikasi (stratified random sample) dengan pengelompokan berdasarkan mata pencaharian penduduk. Intensitas sampling ditentukan sebesar $10 \%$ dari populasi kepala keluarga. Sebaran dan jumlah sample pada masing-masing desa dapat dilihat di Tabel 1.

Tabel 1. Sebaran dan Jumlah Sampel di Desa Dusun Baru I dan Tanjung Terdana

\begin{tabular}{clcccc}
\hline \multirow{2}{*}{ No } & & \multicolumn{2}{c}{ Dusun Baru I } & \multicolumn{2}{c}{ Tanjung Terdana } \\
& & $\begin{array}{c}\text { Jumlah } \\
\text { kk }\end{array}$ & Sampel kk & $\begin{array}{c}\text { Jumlah } \\
\text { kk }\end{array}$ & Sampel kk \\
\hline 1 & Petani & 34 & 4 & 106 & 9 \\
2 & Pegawai Negeri/swasta & 45 & 4 & 6 & 2 \\
3 & Pedagang & 10 & 3 & 4 & 1 \\
4 & Buruhljasa & 51 & 6 & 18 & 2 \\
& & 140 & 17 & 134 & 14 \\
\hline
\end{tabular}

Data konsumsi kayu bakar didapatkan dengan melakukan pengukuran langsung penggunaan kayu bakar dari sampel terpilih. Pengukuran dan penimbangan kayu bakar untuk kegiatan memasak dan untuk pengasapan dilakukan pagi dan sore. Besarnya penggunaan kayu bakar diukur dengan langkah sebagai berikut : (1) menyiapkan kayu bakar yang akan digunakan untuk memasak dan pengasapan ternak setiap pagi dan sore selama 3 hari pada tiap kk terpilih, (2) menimbang kayu bakar yang akan digunakan sebelum dimasukkan ketungku atau perapian, dan mengamati berapa banyak kayu bakar yang digunakan sampai kegiatan memasak/pengasapan selesai, (3) setelah selesai kegiatan memasak/pengasapan, sisa kayu 
bakar ditimbang kembali sehingga diketahui berat kayu bakar yang digunakan untuk memasak/pengasapan. Data hasil penimbangan dikonversi menjadi volume menggunakan angka konversi yang berupa perbandingan volume dan berat kayu kering udara dari masing-masing jenis kayu yang digunakan. Angka konversi tiap jenis kayu didapat dengan menentukan BD kayu berdasarkan metode ASTM (Anonim, 1995 menggunakan 5 sampel untuk masing-masing jenis.

Informasi kondisi sosial ekonomi responden, jenis kayu bakar yang disukai, dan sistem pemungutan kayu bakar dilakukan dengan cara wawancara menggunakan daftar pertanyaan acuan yang telah disiapkan terlebih dahulu.

\section{HASIL DAN PEMBAHASAN}

\section{Konsumsi Kayu bakar}

Hasil penelitian menunjukkan bahwa rata-rata konsumsi kayu bakar per keluarga pertahun di Dusun Baru I sebesar $5.89 \mathrm{~m}^{3}$ dan di Tanjung Terdana sebesar $7.88 \mathrm{~m}^{3}$ (Tabel 2).

Tabel 2. Konsumsi Kayu Bakar di Desa Dusun Baru I dan Tanjung Terdana

\begin{tabular}{llllll}
\hline No & Desa & $\begin{array}{l}\text { Pendapatan } \\
(\mathrm{Rp} / \mathrm{kk} / \mathrm{bln})\end{array}$ & $\begin{array}{l}\text { Jml anggota } \\
\text { keluarga }\end{array}$ & $\begin{array}{l}\text { Konsumsi } \\
\left(\mathrm{m}^{3} / \mathrm{kk} / \mathrm{th}\right)\end{array}$ & $\begin{array}{l}\text { Konsumsi } \\
\text { (m³/desa/ th) }\end{array}$ \\
\hline 1 & Dusun Baru I & $347.882 \pm 111.124$ & $4.8 \pm 1.71$ & $5.89 \pm 2.49$ & 825 \\
2 & Tanjung Terdana & $407.857 \pm 109.346$ & $5.5 \pm 2.02$ & $7.88 \pm 4.14$ & 1056 \\
\hline
\end{tabular}

Angka ini jauh lebih besar jika dibandingkan hasil survey Dirjen Ketenagaaan pada tahun 1980 yang menunjukkan bahwa konsumsi kayu bakar nasional hanya sebesar 4.07 m²/kk/tahun (Kadir 1995). Tingginya tingkat konsumsi kayu bakar di dua desa ini diduga karena penduduk Desa Dusun Baru I dan Desa Tanjung Terdana tidak hanya menggunakan kayu bakar untuk memasak (air, nasi atau lauk-pauk) tetapi juga menggunakan kayu bakar untuk perlindungan hewan ternak dari gangguan nyamuk dengan melakukan pengasapan.

Data responden sebagai pemiliki ternak yang tersaji pada Tabel 3 menunjukkan bahwa hampir empat puluh persen konsumsi kayu bakar di kedua desa digunakan untuk pengasapan ternak Tabel 3.

Tabel 3. Penggunaan Kayu Bakar Responden Pemilik Ternak

\begin{tabular}{clcc}
\hline No & \multicolumn{1}{c}{ Desa } & $\begin{array}{c}\text { Memasak } \\
(\mathrm{m} 3 / \mathrm{kk} / \mathrm{thn})\end{array}$ & $\begin{array}{c}\text { Pengasapan ternak } \\
(\mathrm{m} 3 / \mathrm{kk} / \mathrm{thn})\end{array}$ \\
\hline 1 & Dusun Baru I & $4.79 \pm 2.44$ & $3.21 \pm 0.27$ \\
2 & Tanjung Terdana & $5.91 \pm 2.64$ & $3.24 \pm 0.42$ \\
\hline
\end{tabular}

$\overline{\text { Penggunaan Kayu Bakar Untuk Rumah Tangga di Desa Sekitar TAHURA Rajolelo, Bengkulu ....(Putranto \& Jon) }} 35$ 
Walaupun demikian, hasil analisa korelasi antara jumlah ternak dan penggunaan kayu bakar untuk pengasapan menunjukkan bahwa konsumsi kayu bakar untuk pengasapan ternak tidak dipengaruhi oleh jumlah ternak yang dimiliki. Hal ini dikarenakan sebagian besar ternak yang dimiliki penduduk dikandangkan dalam satu kandang dan pengasapan dilakukan satu buah untuk tiap kandang, sehingga berapapun jumlah ternak yang dimiliki, selama masih dalam satu kandang, keperluan kayu untuk pengasapan sama besarnya.

Diluar penggunaan kayu bakar untuk pengasapan ternak, kebutuhan kayu bakar untuk kegiatan memasak di kedua desa ini masih tergolong tinggi (Tabel 3). Tingginya konsumsi kayu bakar untuk memasak ini disebabkan oleh karena cara memasak yang tidak efisien. Hampir semua responden masih menggunakan tungku yang boros penggunaan kayu, yaitu tungku tradisional satu lobang yang tersusun dari batu bata atau koral berbentuk segitiga dengan masukan kayu bakar dari tiga arah.

Selain itu, tingginya konsumsi kayu bakar di dua desa ini diduga juga karena mudahnya didapatkan kayu bakar di sekitar desa (dari kawasan Tahura). David et al (1996) menyatakan bahwa besarnya konsumsi kayu bakar salah satunya disebabkan oleh ketersediaan pohon yang dapat dimanfaatkan untuk kayu bakar. Karena masyarakat sekitar Tahura masih sangat mudah mendapat kayu bakar dari lahan Tahura maka tidak terfikir untuk melakukan efisiensi.

Akibat penggunaan kayu bakar yang besar tersebut, kerusakan Tahura kemungkinan akan semakin besar Pemakaian kayu bakar sebagai energi terutama oleh penduduk pedesaan sering mengakibatkan kerusakan lingkungan hutan yang sangat serius (Sahidu, 1983). Jika dilihat dari konsumsi kayu bakar oleh penduduk kedua desa tersebut saja maka kawasan Tahura Rajolelo akan terbebani kehilangan kayu sebesar $1800 \mathrm{~m}^{3}$ per tahun.

Hasil perbandingan konsumsi kayu bakar per keluarga antara kedua desa menunjukkan bahwa masyarakat Desa Tanjung Terdana mengkonsumsi kayu bakar lebih besar daripada masyarakat Desa Dusun Baru I (Tabel 2). Perbedaan konsumsi ini kemungkinan disebabkan oleh perbedaan faktor sosial ekonomi, seperti status pekerjaan, pendapatan dan jumlah tanggungan keluarga.

Penduduk Desa Dusun Baru lebih banyak yang brstatus pegawai negeri atau pedagang, dan berpendapatan lebih tinggi, sementara penduduk Desa Tanjung Terdana sebagian besar adalah petani dengan pendapatan yang lebih rendah (lihat Tabel 2). Kondisi status sosial yang dianggap lebih tinggi ini menyebabkan adanya kecenderungan penduduk Dusun Baru I (35.3\%) 
menggunakan bahan bahan bakar alternatif (minyak tanah) lebih besar dibanding penduduk Tanjung Terdana (21.43\%).

Rata-rata jumlah anggota keluarga penduduk Tanjung Terdana (5.5 orang) yang lebih besar dari penduduk Desa Dusun Baru I (4.8 orang) juga menyebabkan tingkat konsumsi kayu bakar lebih banyak. Semakin banyak jumlah anggota keluarga maka kebutuhan kayu bakar akan semakin banyak karena volume bahan yang harus dimasak juga semakin banyak. Hal ini seperti yang disampaikan Madjid (1998) dan Dewi (1996) bahwa kebutuhan kayu bakar untuk memasak dipengaruhi oleh banyaknya bahan makanan yang dimasak dan rumah tangga yang mempunyai anggota keluarga semakin besar maka konsumsi kayu bakarnya semakin besar pula. Dari hasil analisa regresi linier sederhana dan analisa korelasi antara konsumsi kayu bakar dan jumlah anggota keluarga didapatkan nilai koefisien korelasi sebesar 0.9645 yang berarti keeratan hubungan antara kedua variable sangat tinggi. Analisa regresi memberikan persamaan $Y=$ $2.0206 \mathrm{X}-3.3098$ yang menunjukkan bahwa setiap peningkatan satu unit anggota keluarga meningkatkan $2.0205 \mathrm{~m} 3$ kayu bakar per tahun.

\section{Alasan Penggunaan Kayu Bakar}

Sebagian besar penduduk menyatakan bahwa mereka menggunakan kayu bakar karena alasan kebiasaan atau tradisi yang sudah turun temurun seperti tersaji pada Tabel 4.

Tabel 4 Alasan Penggunaan Kayubakar Sebagai Bahan Bakar

\begin{tabular}{llll}
\hline No & Alasan & Dusun baru I & Tanjung Terdana \\
\hline 1 & Tradisi/ Kebiasaan & $13(76.47 \%)$ & $4(28.57 \%$ \\
2 & Tekanan Ekonomi & - & $5(35.71 \%)$ \\
3 & Minyak Tanah Susah & - & - \\
4 & Kayu Bakar Mudah didapat & $4(23.52 \%)$ & $5(35.71 \%)$ \\
\hline
\end{tabular}

Kayu bakar merupakan sumber panas paling tua yang mudah diperoleh dan mudah ditangani oleh masyarakat pedesaan (Majid, 1998). Masyarakat kedua desa ini telah lama mengenal dan menggunakan kayu bakar sebagai sumber energi untuk memasak. Dengan sudah lamanya dikenal dan digunakannya kayu bakar maka timbul keterikatan yang mentradisi di dalam masyarakat. Beberapa responden menyatakan bahwa memasak nasi atau lauk dengan kayu bakar akan memberi rasa lebih enak daripada dengan kompor, selain itu dikatakan juga bahwa dalam proses pemasakan, asap yang keluar dipercayai memberikan aroma khas bagi makanan yang dimasak. Keterikatan ini yang menyebabkan kayu bakar masih digunakan walaupun ada alternatif penggunaan bahan bakar lain. 
Ketersediaan kayu bakar juga merupakan alasan masyarakat menggunakan kayu bakar untuk keperluan rumah tangganya. Sampai saat ini Tahura masih merupakan sumber kayu bakar yang berlimpah dan relatif gratis bagi penduduk kedua desa. Selain itu tekanan ekonomi juga merupakan salah satu alasan penggunaan kayu bakar. Masyarakat yang berpenghasilan rendah menggunakan kayu bakar karena relatif bisa didapat dengan gratis (bisa didapatkan tanpa mengeluarkan uang ).

\section{Jenis dan Teknik Pemungutan Kayu Bakar}

Jenis tanaman pohon yang digunakan sebagai kayu bakar oleh penduduk Dusun Baru I dan desa Tanjung Terdana dapat dilihat pada Tabel 5. Dari tabel tersebut tampak bahwa jenis pohon yang paling banyak digunakan adalah Laban (Vitex pinnata), selain itu yang banyak digunakan adalah Kemutun (Cratoxylon formosum), Merampuyan (Rhodamnia vinerea), Pelangas (Aporosa aurita) dan Kayu gadis (Cinnanomum porrectum). Kayu-kayu lunak seperti Pulai (Alstonia scholaris) dan Sengon (Paraserianthes falcata) yang juga banyak tersedia tidak digunakan untuk kayu bakar. Kayu dari jenis pohon buah buahan juga sedikit digunakan, hanya kayu nangka dan durian yang digunakan sebagai kayu bakar.

Tabel 5. Jumlah dan Persentase Responden Pengguna dan Penyuka Jenis-jenis Kayu Bakar di Desa Dusun Baru I dan Tanjung Terdana

\begin{tabular}{clcccc}
\hline No & \multirow{2}{c}{ Jenis Kayu } & \multicolumn{2}{c}{ Dusun Baru I } & \multicolumn{2}{c}{ Tanjung Terdana } \\
& & Pengguna & Penyuka & Pengguna & Penyuka \\
\hline 1 & Laban (Vitex pinnata) & $17(100 \%)$ & $17(100 \%)$ & $12(85.6 \%)$ & $12(85.7 \%)$ \\
2 & Pelangas (Aporosa aurita) & $14(82.4 \%)$ & $5(29.4 \%)$ & $11(78.6 \%)$ & $7(50 \%)$ \\
3 & Merampuyan (Rhodamnia cinerea) & $8(47.1 \%)$ & $2(11.8 \%)$ & $11(78.6 \%)$ & $7(50 \%)$ \\
4 & Gelam (Syzigium racemosum) & $3(17.7 \%)$ & $1(5.9 \%)$ & $2(14.3 \%)$ & - \\
5 & Kemutun (Cratoxylon formosum) & $9(52.9 \%)$ & $2(11.8 \%)$ & $9(64.4 \%)$ & $5(35.7 \%)$ \\
6 & Ky gadis (Cinnamomum porrectum). & $5(29.4 \%)$ & - & $9(64.4 \%)$ & $3(21.4 \%)$ \\
7 & Merabikang (Ixonanthes petiolaris) & $1(5.9 \%)$ & - & - & - \\
8 & Durian (Durio Zhibetinus) & $2(11.8 \%)$ & - & $1(7.1 \%)$ & - \\
9 & Kedung (Symplocos cochinchinensis) & $1(5.9 \%)$ & - & $2(14.3 \%)$ & - \\
10 & Gamet (Elaeocarpus glaber) & - & - & $2(14.3 \%)$ & - \\
11 & Kapening (Lithocarpus sundaica) & - & - & $1(7.1 \%)$ & - \\
12 & Nangka (Arthocarpus intergrifolia) & - & - & $2(14.3 \%)$ & - \\
13 & Salung (Psycnotria viridiflora) & - & - & $2(14.3 \%)$ & - \\
14 & Kemuning (Memecylon myrsinoides) & - & - & $2(14.3 \%)$ & - \\
15 & Johar (Cassia siamea) & - & - & $3(21.4 \%)$ & - \\
16 & Jengkol (Archidendron jiringa) & - & - & $1(7.1 \%)$ & - \\
17 & Bangan (Castanopsis inermis) & - & - & $1(7.1 \%)$ & - \\
\hline
\end{tabular}


Dari tujuh belas jenis yang digunakan hanya ada enam jenis pohon yang disukai penduduk sebagai kayu bakar yaitu Laban, Pelangas, Merampuyan, Kemutun, Gelam dan Kayu Gadis. Jenis ini disukai karena kayunya tahan lama, api tidak mudah padam dan nyala bagus sehingga dalam proses memasak bisa lebih cepat. Oleh karena jenis pohon yang disukai masih banyak terdapat di Tahura, jenis lain tidak menjadi pilihan. Sampai saat ini, untuk memenuhi kebutuhan kayu bakar, sebagian besar masyarakat desa Dusun Baru I dan Tanjung Terdana hanya memanfaatkan cabang dan ranting pohon yang sudah kering (Tabel 6).

Tabel 6. Bagian Pohon Yang Digunakan Sebagai Kayu Bakar

\begin{tabular}{clcc}
\hline \multirow{2}{*}{ No } & Bagian yang digunakan & \multicolumn{2}{c}{ Responden (\%) } \\
\cline { 3 - 4 } 1 & Cabang/ranting yang mati & $17(100 \%)$ & $11(78.6 \%)$ \\
2 & Batang & - & - \\
3 & Semuanya (menebang) & - & $3(21.4 \%)$ \\
\hline
\end{tabular}

Penduduk memungut kayu dari lantai hutan atau dari pohon yang tumbang dan membawanya dengan menggunakan keranjang (beronang) yang talinya diikatkan kekepala. Sebagian besar penduduk hanya mengambil kayu yang berukuran $3-10 \mathrm{~cm}$ diameter. Hal ini dikarenakan keterbatasan angkat angkut yang berupa keranjang. Dengan sistem pengambilan tersebut maka kemungkinan dampak negatif kerusakan hutan masih sangat terbatas. Namun demikian, beberapa responden juga sudah mulai mengambil kayu bakar dengan cara menebang pohon. Penduduk yang melakukan penebangan biasanya juga melakukan transaksi jual beli kayu bakar. Kegiatan penebangan ini perlu mendapatkan perhatian khusus.

Frekuensi, Waktu Pengambilan dan Pencari Kayu Bakar

Data frekuensi pengambilan kayu bakar, waktu pengambilan dan anggota keluarga yang berperan mencari kayu bakar disajikan pada Tabel 7. Frekuensi pengambilan kayu bakar bervariasi dari satu keluarga ke keluarga lain. Sebagian besar frekuensi pengambilan kayu bakar oleh penduduk dilakukan seminggu sekali atau bahkan lebih lama. Pengambilan dilakukan dalam jumlah yang cukup besar kemudian disimpan di halaman atau kolong rumah untuk memenuhi kebutuhan sampai pengambilan berikutnya. 
Tabel 7. Frekuensi, Waktu Pengambilan dan Pencari Kayu Bakar

\begin{tabular}{|c|c|c|c|}
\hline No & Keterangan & Dusun Baru I & Tanjung Terdana \\
\hline \multicolumn{4}{|c|}{ Frekuensi: Pengambilan Kayu } \\
\hline 1 & Setiap Hari & $11.8 \%$ & $14.3 \%$ \\
\hline 2 & Setiap 3 hari & $17.6 \%$ & $14.3 \%$ \\
\hline 3 & Setiap 1 Minggu & $64.7 \%$ & $14.3 \%$ \\
\hline 4 & Lebih dari 1 Minggu & $5.9 \%$ & $57.1 \%$ \\
\hline \multicolumn{4}{|c|}{ Waktu Pengambilan Kayu } \\
\hline 1 & Selesai Bekerja & - & $7.1 \%$ \\
\hline 2 & Sambilan waktu ke sawah/ladang & $11.8 \%$ & $28.6 \%$ \\
\hline 3 & Disiapkan waktu khusus & $88.2 \%$ & $64.3 \%$ \\
\hline \multicolumn{4}{|c|}{ Pencari Kayu Bakar } \\
\hline 1 & Suami & $11.8 \%$ & - \\
\hline 2 & Istri & $70.6 \%$ & $78.6 \%$ \\
\hline 3 & Anak Laki-laki & - & - \\
\hline 4 & Anak Perempuan & $17.6 \%$ & $21.4 \%$ \\
\hline
\end{tabular}

Dalam mencari kayu bakar, selain dilakukan setelah selesai bekerja atau sambilan sewaktu pergi ke sawah, kebun atau ladang, sebagian besar masyarakat menyediakan waktu khusus untuk mencari dan mengumpulkan kayu bakar. Pengambilan kayu bakar dengan waktu khusus dan selang waktu yang cukup lama ini dilakukan karena masyarakat merasa lebih efisien untuk mencari kayu bakar sekaligus dalam jumlah banyak kemudian disimpan di dekat rumah daripada mencari dalam jumlah sedikit tetapi harus melakukannya terus menerus.

Di antara anggota keluarga, yang berperan mencari kayu bakar adalah kaum perempuan, baik isteri maupun anak perempuan. Hal ini diduga karena dalam masyarakat tradisional urusan dapur/masak memasak masih dianggap tugas perempuan sehingga kegiatan mencari kayu bakar yang umumnya digunakan untuk memasak juga dibebankan pada perempuan. Arisanti (1996) mengatakan bahwa perempuan di Indonesia menghabiskan waktunya kira-kira 3 jam per hari untuk memasak dan 4 jam seminggu untuk mengumpulkan kayu bakar. Sementara Nathan (1997) juga melaporkan bahwa sebagian besar kaum wanita di Indonesia menghabiskan waktunya di dapur, termasuk di dalamnya mengumpulkan kayu bakar dari hutan kebun dan ladang. Peran perempuan dalam kegiatan mencari kayu bakar harus dicermati sehingga pembenahan pengelolaan hutan sebagai penghasil kayu bakar ataupun pengenalan teknologi pemanfaatan bahan bakar alternatif harus lebih menyentuh kaum perempuan daripada laki-laki. 


\section{KESIMPULAN}

Dari hasil penelitian nampak bahwa; (1) konsumsi kayu bakar penduduk desa Dusun Baru I dan desa Tanjung Terdana sangat besar, yaitu $5.89 \pm 2.49$ m³/kk/tth untuk Dusun Baru I dan $.88 \pm 4.1 \mathrm{~m} 3 / \mathrm{kk} /$ th untuk Tanjung Terdana, (2) tingginya konsumsi kayu bakar ini disebabkan oleh kegiatan pengasapan ternak dan penggunaan tungku masak yang kurang efisien, (3) tingkat konsumsi kayu bakar dipengaruhi oleh jumlah anggota keluarga, (4) secara umum sistem pemungutan kayu bakar masih ramah lingkungan, walaupun sudah mulai ada kecenderungan kegiatan penebangnn pohon untuk kayu bakar dan (5) perempuan memegang peran penting dalam memenuhi kebutuhan kayu bakar untuk rumah tangga.

\section{DAFTAR PUSTAKA}

Anonimus, 1987. Pola Pembakaran Tradisional Bertendensi Menurun. Majalah Kehutanan Indonesia. No 26/1987.

Anonimus, 1995. Annual Book of ASTM Standard. ASTM, Philadelphia, USA

Aristanti C, 1996. Gender, Biomass Energy and Health. Wood Energy News. Vol 12. No1. Regional Wood Energy Development Program in Asia (GCP/RAS/154/NET)

David, Syamsudin, Mody, dan Hermin, 1996. Konsumsi Kayu Bakar oleh Rumah Tangga pada Tiga Kabupaten di Propinsi Sulawesi Selatan. Jurnal Penelitian Kehutanan. X (1). BPK Ujung Pandang.

Dewi, HQ, 1994. Studi Pemenuhan Kebutuhan dan Produksi Kayu Bakar di Desa-desa Sekitar Hutan Ketu BKPH Wonogiri KPH Surakarta. Jur Manajemen Fahutan IPB (Unpublished research paper)

Kadir, A, 1995. Energy, Sumberdaya, Inovasi, Tenaga Listrik dan Potensi Ekonomi. Univertias Indonesia Press. Edisi II. Jakarta.

Madjid, HD, 1998. Pola Konsumsi Kayu Bakar oleh Rumah Tangga di Daerah Kabupaten Magelang. Jurusan Manajemen Hutan Fahutan IPB (Unpublished research paper).

Nathan,D, 1997. Economic Factor in Adoption of Improved Stove. Wood Energy News. Vol 12 No.1. Regional Wood Energy Development Programme in Asia (GCP/RAS/154/NET)

Sahidu, S, 1983. Kotoran Ternak Sebagai Sumber Energi. Penerbit Ruci Press. Jakarta. 